\title{
Classroom acts: New materialisms and haptic encounters in an urban classroom
}

\author{
Alyssa D. Niccolini \\ Teachers College, Columbia University adn2106@tc.columbia.edu \\ Maya Pindyck \\ Teachers College, Columbia University ${ }^{1}$ mrp2019@tc.columbia.edu
}

\begin{abstract}
In this piece we work with new materialist theory to experiment with the objects within a United States (US) secondary classroom in New York City (NYC). Energized by Katarina Kamprani's (ongoing) "The Uncomfortable Project," in which she renders everyday objects unfamiliar, we brought in unfamiliar items to a NYC classroom to change our relations to it and its relations to us. We consider how a paranoid affective relationship to 'the urban classroom' has limited engagement with classroom objects as lively, self-organizing, and haptically-rich with their own forms of agency and affective force. We explore a methodology of felting in which the textures of the classroom are agitated and worked to elicit surprising affects, unexpected connections, and new materialities. We see such an engagement as offering new possibilities for encountering educational spaces and as eliciting more reparative (Sedgwick, 2003) forms of theorizing and learning from urban classroom space.
\end{abstract}

Keywords: new materialism, affect, classroom objects, space, intimacy, bodies

There were elements to consider-ones we couldn't have predicted. How the Friday afternoon light made squat desks and the grey veneer of lockers suddenly beautiful. The apple, like a sign or a peal of laughter, sitting on the hallway floor by the stairwell, as if to say: "It's already here, already happening" (Figure 1). The metal frame announcing a missing clock (Figure 2). The dolls-one blonde, one brunette-facing off on a bookshelf (Figure 3). Phrases, words, and letters floating around the classroom with their own mad logics: "Pathogens Gallery Walk" (Figure 18), "Missing Immune System Response Project," "Impulse Pathways" (Figure 8), "Carina loves Anthony." The letter "A" slapped on the door like a varsity coach high-fiving us on entrance (Figure 4). The faint tracing of a cat's head with a penis in its mouth on the chalkboard (Figure 16). The grids of neon post-it notes pooling in the corner (Figure 6). The room became more than the familiar landscape of the classroom, signaling to us in some way or another.

\footnotetext{
${ }^{1}$ There is no first or second author to this paper; both authors contributed equally.
} 
Classroom acts 2

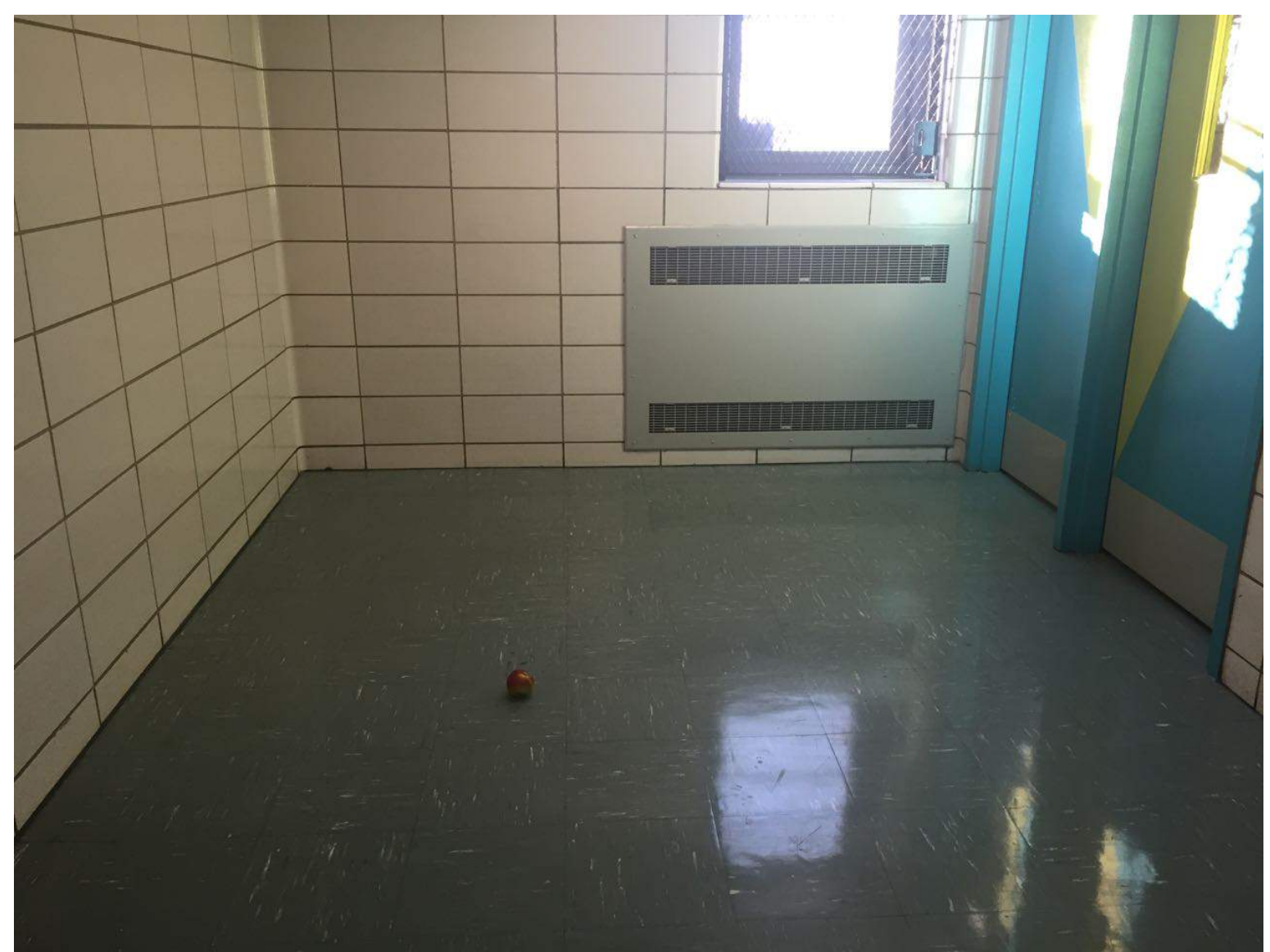

Figure 1- "Apple"-Hallway entrance.

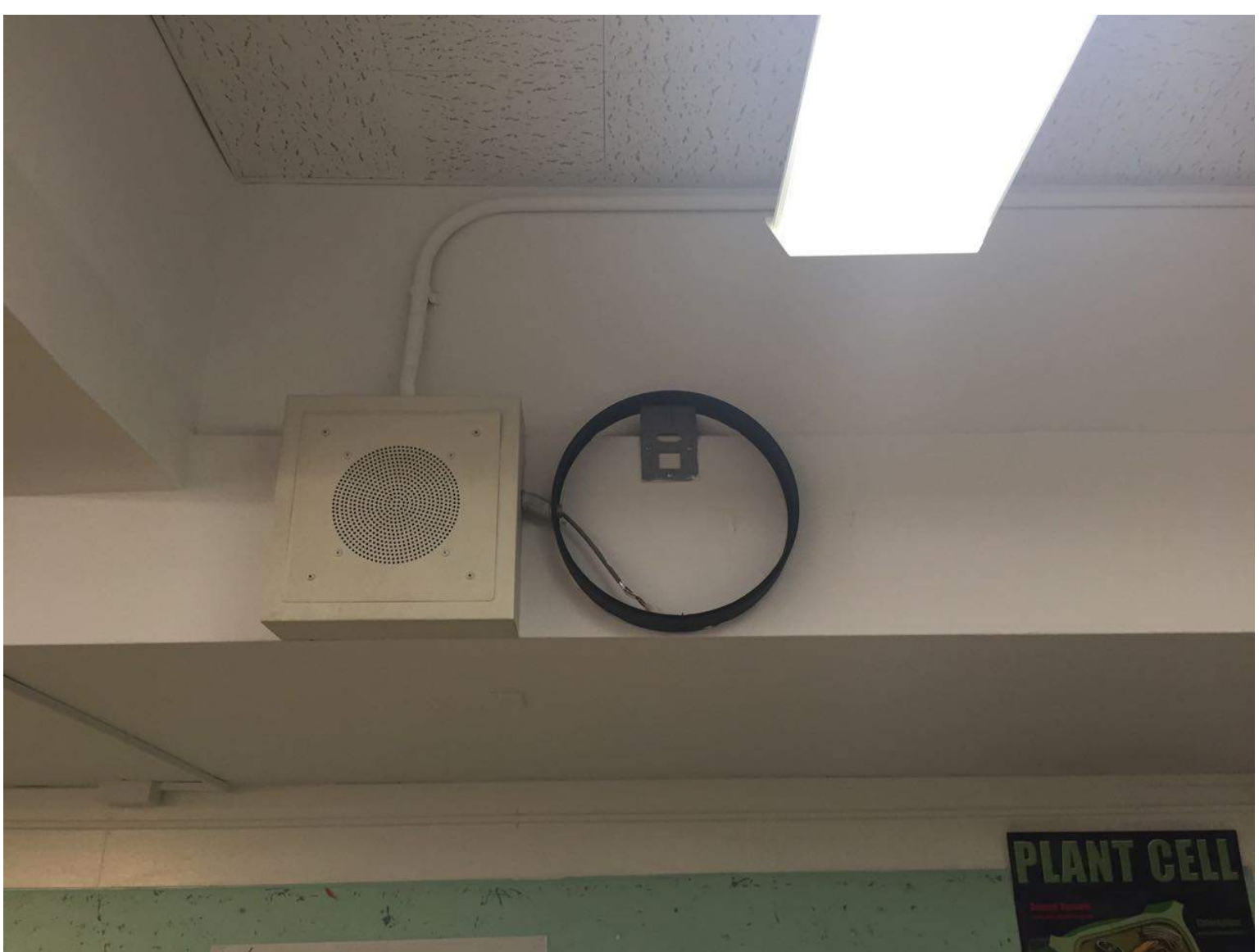

Figure 2- "Announcement"-Missing clock. 


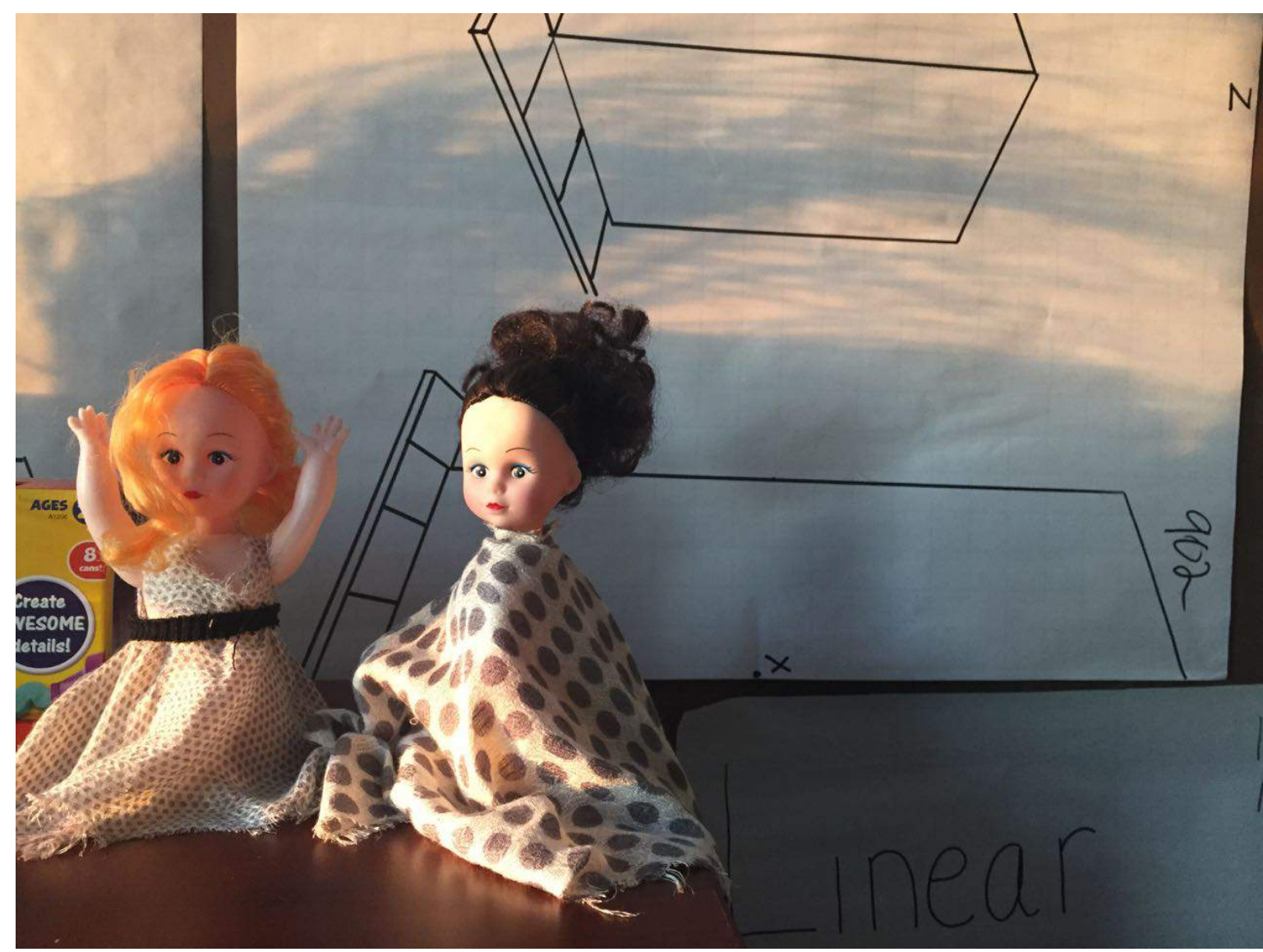

Figure 3- "Linear"-Dolls on a classroom bookcase.

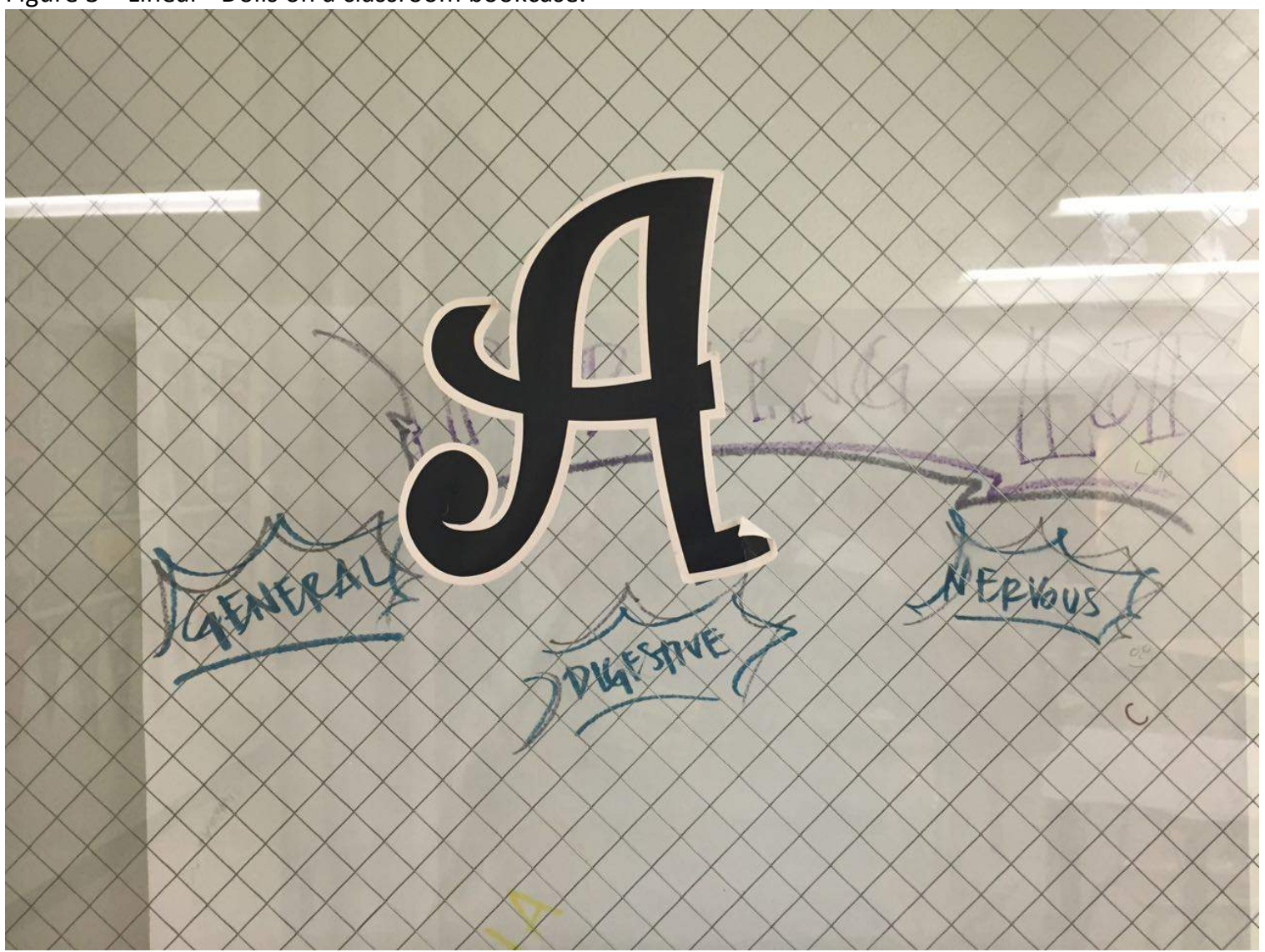

Figure 4- "General/Digestive/Nervous"-Varsity A on entrance to classroom. 


\section{Intimacies}

What happens when we change our intimacy practices with a classroom space? What happens when we get closer than we are supposed to, or when we dwell within its textures, touch its surfaces, and stay too long? What happens when we mix hair and bodily fluid with the melamine of desks, or when we affect and are affected by the vibrancy of classroom matter (Bennett, 2010)?

Inspired by new materialist theory (Barad, 2007; Bennett, 2010; Chen, 2013; Dolphijn \& van der Tuin, 2012) and designer Katarina Kamprani's (ongoing) "The Uncomfortable Project," in which she renders everyday objects useless, this piece seeks to skim along the surfaces particular to United States (US) schooling and play with the objects of a New York City (NYC) classroom. Deleuze and Guattari (1983) offer up experimentation as an alternative to interpretation. This project experiments with objects in a classroom to explore how matter matters. Those nonhuman or morethan-human objects act as dynamic agents, or as Bennett (2010) has it "actants," active bodies in the "body of the classroom" (Dernikos, 2015).

Initially, we imagined this project an art installation in a public high school classroom, however, we were repeatedly stymied by striations of schooling, such as the year-end testing, school restrictions on guest access, and professional development meetings, that rendered the classroom spaces 'offlimits'. Both the immanent presence of State tests (a staple of the US system of education and increasingly so under the current Common Core State Standard initiatives) and bureaucratic, administrative hurdles re-oriented us to make necessary adjustments. Since it seemed impossible to find a site through permission, we decided, instead, to perform small interventions (like covering a chalkboard completely in chalk and then erasing it, or methodically flipping over a row of chairs) covertly in the spaces we taught. We performed small interventions quietly, in whatever classrooms we found ourselves in as teachers. As a result, the first phase of this project became a concealed operation-a kind of mission impossible - stammering across unplanned times and not-quite-right spaces. Eventually, a friend and former colleague agreed to let us use her high school science classroom for our project. When we arrived, teachers and administrators were still in the school, lingering in their classrooms and throughout the building. At times we conducted our stagings excitedly, running about the room, standing on desks, and energetically arranging objects. At other times we moved timidly, fearing we would get the teacher in trouble if a passerby saw a knife on the chalk shelf, for example. We wondered, were we colonizing her classroom? Were we taking advantage of her generosity? We chatted with our friend, ate her leftover lunch, moved about the classroom, and pointed out enchanting or surprising finds. We arranged and staged scenes, brought our faces close to surfaces, poured liquids and powders on desks, and photographed the outcomes. Our experiments in the classroom followed Osgood and Giugni's (2015) onto-epistemological enquiries, "What counts as data? What does data do? And what do we do with what the data does?" (p.347).

Two weeks after the classroom intervention, we printed the photos. Marks (2002) mobilizes video stills, photographs and images as conduits to "a trace of the originary, physical event" (p.xi). The image acts as "connective tissue" ( $p . x i)$ between past and present, actual and virtual, touch and memory. We met to look at the photos together, spreading them out on the floor of Maya's bedroom, mapping assemblages on chart paper, and then responded to each other's writings and combinations. We become an active body as we moved through the data, travelling around the room, trying not to step on the markers, photos, and limbs scattered on the floor. We created patternings of the images that evoked film reels or belts of image (Figure 5) and would step back and squint at our arrangements to amplify blocks of color and skim the assemblages of images. 


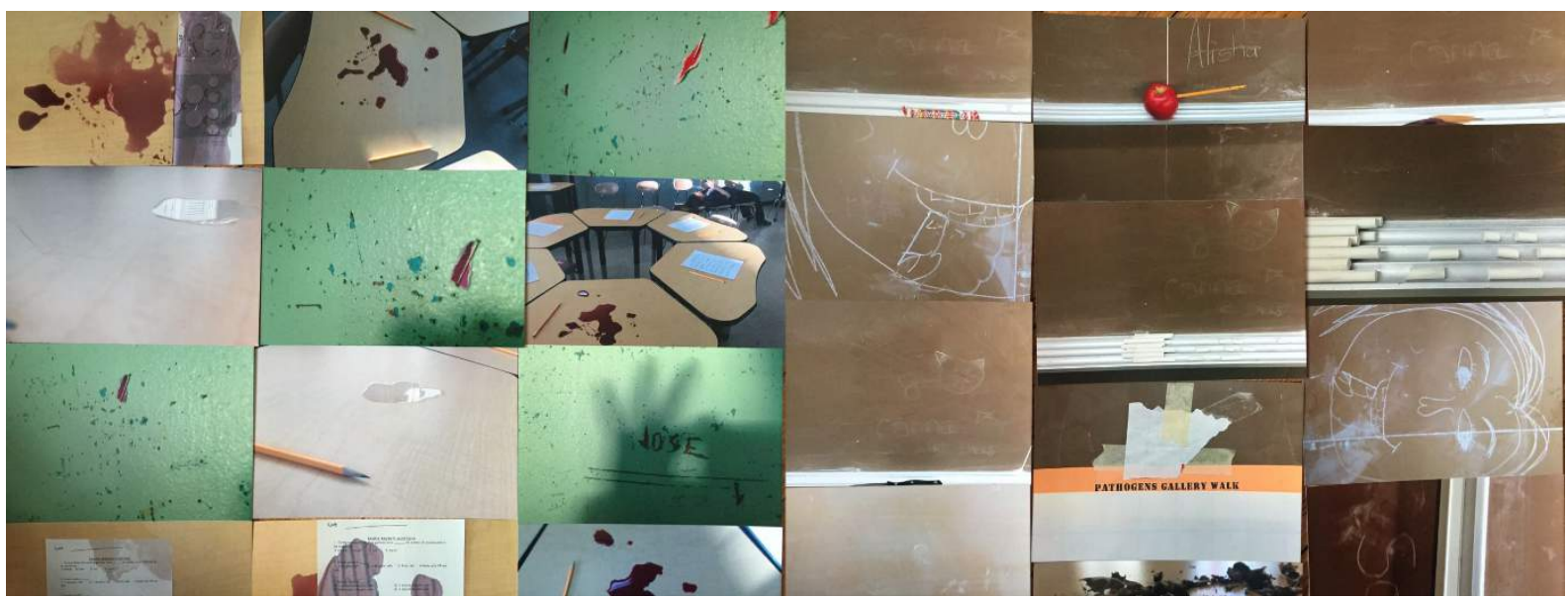

Figure 5- "Patternings" - Photo grids

Our project was inspired by Kamprani's (ongoing) simple interventions in familiar objects--how a small hole in the bottom of a pink bowl completely changes our relation to it and jolts us out of its familiar use and taken-for-granted function. Each of the everyday objects she presents--a chair with an uptilted seat, a fork with limp prongs, a concrete umbrella, a watering can with spout turned back into reservoir--frustrates human agency and expectations. These utilitarian misfirings derail how we project ourselves into the future of an object, disrupting a telos-driven progress and taken-forgranted kinship. Right away she confronts us with inefficiency and uselessness in terms of commonsense imaginations of functionality. The objects force a moment of hesitation--they sustain and suspend time and disrupt a flow. Resonating with what Ranciere (2004) calls interchangeably "politics" or "aesthetics," these interventions "redistribute the sensible" of everyday objects; no longer useful in a common sense way, these "useless" objects throw us off, viscerally dis-orienting us in relation to the things we know, or thought we knew. The objects, thus, amplify new affective forces. Kamprani's (ongoing) interventions seem invested in the possibility of sparking unforeseen sensations and feelings towards a no longer common-sense use. Like Ranciere (2004), we recognize a "politics" in the act of making-- or trying to make--a person pause, notice, feel anew those objects and subjects constituting an everyday state of things and to thereby disrupt that everyday flow-- a flow that elicits a kind of comfort, complacency, and numbness to perceptions. Though there is a human predicated in this process of encounter, Kamprani's objects also signal toward an affective force. The objects do something rather than merely are something. While we acknowledge how these objects redistribute human sensibilities, we equally acknowledge how these classroom bodies generate their own forms of intelligence and vibrancy (Bennett, 2010) independent from extensions of human will and agency. 


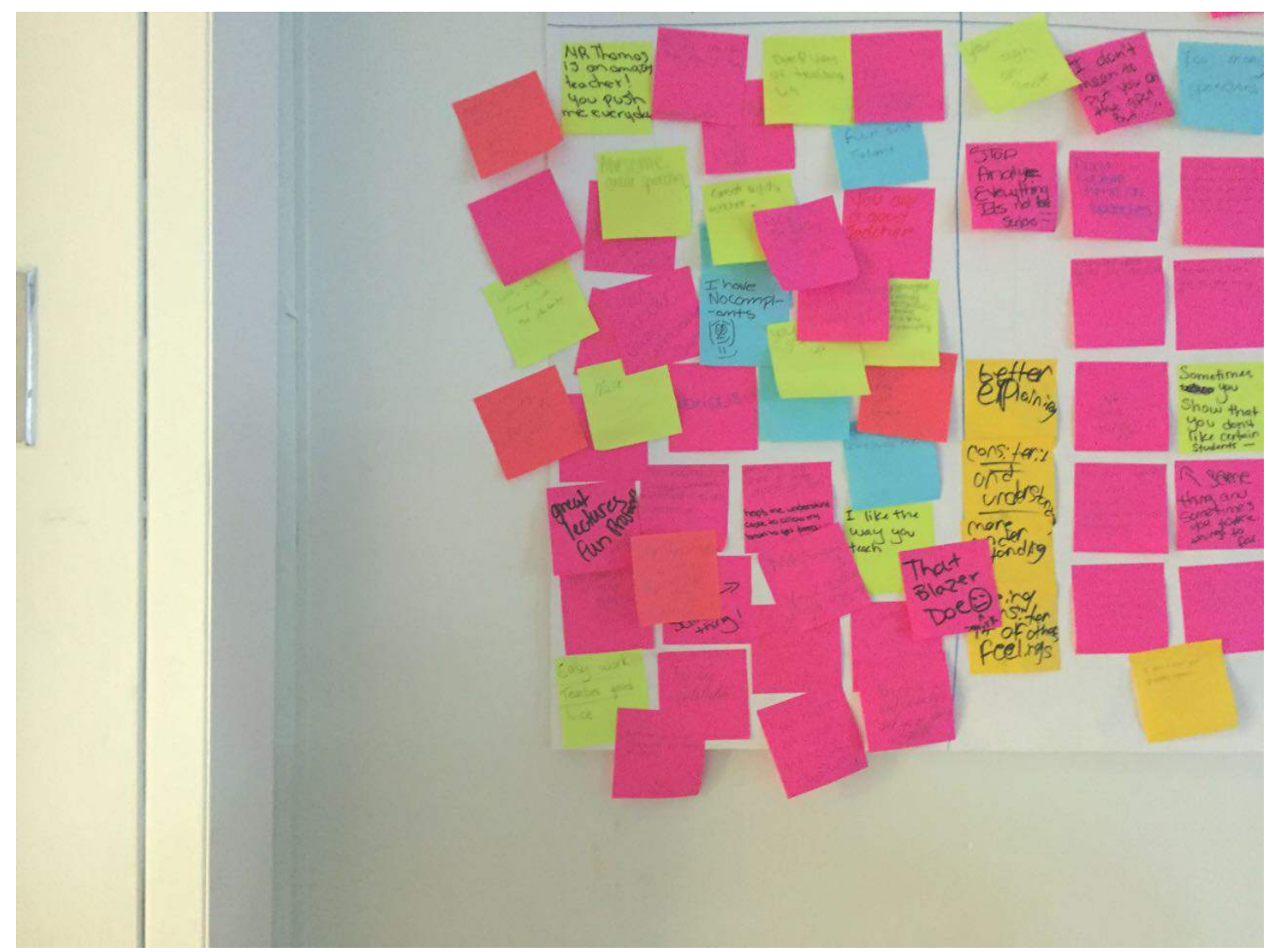

Figure 6- "Neon Swarm" - Post-it notes on chart paper.

A growing body of new materialist work is shifting thinking about school spaces and educational research (see Bodén, 2015; Daza and Gershon, 2015; Dernikos, 2015; Ellsworth, 2005; Fox \& Alldred, 2015; Helfenbein, 2015; Helmsing, 2015; Huddleston, 2015; Juelskjær, Staunæs \& Ratner, 2013; Leander, Phillips and Taylor, 2010; MacLure, 2013; Mulcahy, 2012; O'Donaghue, 2006; Osgood, 2014; 2015; Osgood \& Scarlet, 2015; Renold and Ivinson, 2014; Ringrose and Renold, 2015; Rotas, 2014; Snaza, 2015; Springgay and Rotas, 2014; Taylor, 2013; Taylor \& Ivinson, 2013; Thiel, 2015; Truman, 2015; Zaliwiska, 2015, among others). The vast majority of educational research focuses on the human bodies in classrooms and the human intentions acting in and on the classroom. Rarely are nonhuman bodies the focus of research. When the "mundane materialities" (Taylor, 2012) that traditionally shape the landscape of the classroom (e.g. desks, chairs, boards, overhead lights) get discussed, they are usually done so in relation to how they serve the classroom's human members. In other words, educational studies tend to frame and consider classroom matter as a means to an end and as existent only for human forms of agency. For example, a particular arrangement of desks might be viewed as more "democratic" than another, or a classroom configuration of objects presented as more conducive to group work. Multimodal technologies are often theorized as tools for student learning that are "culturally relevant" objects that make learning more personally meaningful and accessible to minority students. Juelskjær, Staunæs \& Ratner (2013) offer a generative model of how to differently imagine school materialities. They examine the affective draws of the ubiquitous "Freudian couch" in administrative offices. Likewise, Taylor (2014) explores "mundane materialities," such as a teacher's chair and a classroom flipchart, in a UK college classroom to explore how "material moments" help us "to rethink teacher-student-space-object relations as an intra-active co-constitutive accomplishment which show materially that some bodies (and some chairs!) matter more than others" (p.694-5). She follows how gendered dynamics intra-act (Barad, 2007) with classroom materialities. Renold, Ivinson, Eliot and Thomas (in progress) refashioned everyday school rulers into a "ruler-skirt" to explore gender dynamics and sexual violence with UK teen girls. Rotas (2014) explores how GoPro cameras offer new ways to encounter 
urban schooling space, while Renold and Mellor (2013) remap a UK nursery as a multisensory space of gendered becomings.

Our study also attempts to approach and encounter inanimate, nonhuman, and/or more-thanhuman school objects and spaces as dynamic and generative matter(s) (Bennett, 2010). We seek to move "horizontally" with the materialities of the classroom "to begin to experience the relationship between persons and other materialities [...] to take a step toward a more ecological sensibility" (Bennett, 2010, p.10). The science classroom already had its own curriculum-specific coded matter. There were posters on the walls with cross-sections of plant cells, sample state tests on mitosis and meiosis, pebbles, a bag of owl pellets and rat bones. The room was also used one period a day by an art teacher so that the science-coded objects were transected by posters about colour values, crosshatching, contouring, and stippling (Figure 7). This mixture of posters called forth the sometimes warm and at other times uncomfortable intimacies of sharing precious space in a NYC school. These mixtures also underscored our own crosshatched movements alternately coded as 'science' (e.g. social science educational research) and 'art' (e.g. still-life, tableaux, photography).

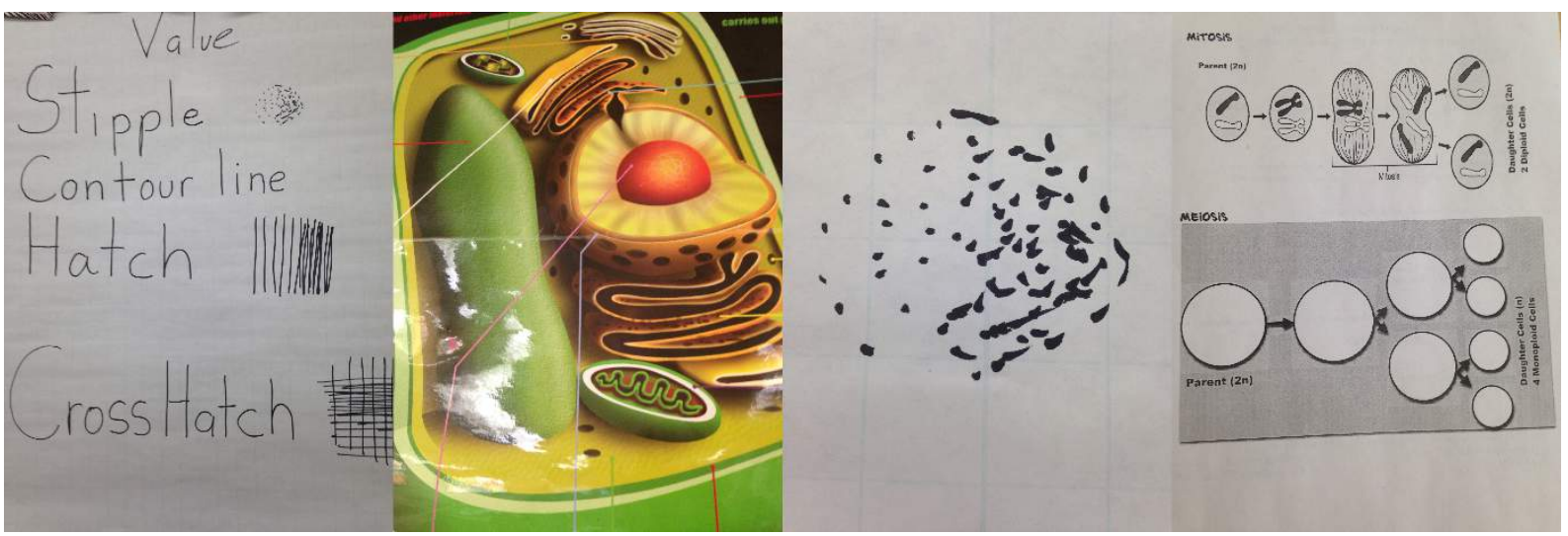

Figure 7- "Crosshatch"-Classroom visuals.

\section{Impulses}

The classroom acts and we act. We were guided by the Spinozist inspired question: What might a classroom do? We see ourselves and the objects intra-acting (Barad, 2007), or acting as "entangled agencies" (p. 33) mutually constituting each other. As opposed to the common sense notion of "interaction" that assumes there exists some stable identity prior to relation, "intra-action" recognizes that things get distinctly made in relation to the other things. Excited by Barad's (2012) notion of touch as an always-present invocation of the other, or an act that exposes the self in the stranger and the stranger in the self, we considered our relationships to these classroom objects and what impulsive acts of touching them might reveal and do. We perceive our research in the classroom as involving a molecular shaping between us (researchers, teachers) and our subjects (classroom objects) - palimpsests of touches newly made in the process of our relationality. We consider the broader implications of "intra-action" to education, particularly the ways in which classroom spaces tend to get viewed and treated as inert spaces made meaningful by humans. Furthermore, like Barad (2012), we believe that theorizing is a mode of experimenting that asks us to be in touch, alert, and responsive to the world's - or the classroom's - "patternings and murmurings" (p. 207). In a sense, this experiment/theory with tactile stagings and skimmings sensitized us (through feeling) to feel those no-longer-familiar objects with which we became newly entangled.

US urban school buildings, in particular, have been theorized hierarchically, or what Bennett (2010) deems vertically, as spaces where objects discipline bodies, particularly bodies of colour (see Fine \& 
Ruglis, 2009; Kozol, 2012, among others), and though we acknowledge the importance of this focus, we wondered what shifting our gaze might contribute to thinking with urban school spaces. Yet, we must also acknowledge the privilege that allows our white, able, and adult bodies to even imagine the urban classroom as a site for research. There is an implicit sense of mastery and at-home-ness afforded to our bodies in these spaces that is not granted to others, particularly youth of colour. For example, a male student of colour bringing a knife into an urban classroom could fear arrest, incarceration, or perhaps, as the fates of Tamir Rice, Eric Garner, Micheal Brown, Akai Gurley, and Walter Scott (among countless others) forewarn, even death. That we did not even entertain this fear bespeaks the way certain bodies are privileged while others are criminalized and even terrorized in US and global landscapes. Yet while this knowledge haunts our project, we were also wary of how well-trained we were becoming at seeing classrooms as disciplining, hierarchizing, and hostile spaces in our own research. Sedgwick's (2003) urgings to watch out for paranoid modes of theorizing prompted us to try and experience the classroom though a more reparative mode. As Sedgwick (2003) warns:

suspicious archaeologies of the present, the detection of hidden patterns of violence and their exposure [are] infinitely doable and teachable protocols of unveiling that have become the common currency of cultural and historicist studies. If there is an obvious danger in the triumphalism of a paranoid hermeneutics, it is that the broad consensual sweep of such methodological assumptions [...] if it persists unquestioned, unintentionally impoverish the gene pool of [...] perspectives and skills. (p. 142-143)

Sedgwick (2003) characterizes such paranoia as "strong theory" (Tomkins, 1995). Strong theory seeks to diminish affectivity by minimizing surprise and potential humiliation. A strong theory seeks selfcongratulatory confirmation for its suspicions in vast topologies of experiences and repeatedly amplifies negative affects, such as paranoia, with each new piece of data. We caught ourselves engaging US urban schools through a paranoid lens -Look a security desk! Look a camera! Look at all these technologies of surveillance! Discipline! Control! Oppression! Our theories of the classroom were becoming too strong and we wondered what they were disallowing us from seeing, experiencing, or imagining. We wondered what might happen if we did not encounter the urban classroom as a disciplinary space configured through human intentions of control and mastery and instead saw it as a space with its own force and agency. As former urban public school teachers, we and our students often encountered school space as a place of surprise, beauty, unexpected combinations, and sensory ecstasies. Though we do not want to romanticize the classroom or ignore the uncomfortable or bad feelings generated by under-funded and poorly-maintained US urban schools, we were spurred by a curiosity about how we might reorient our bodily registers to the classroom and how the space was working and responding to us. We see the classroom as a responsive participant in schools that acts as a live wire, a tangle of nerve pathways, touching and being touched by the bodies that congregate in it.

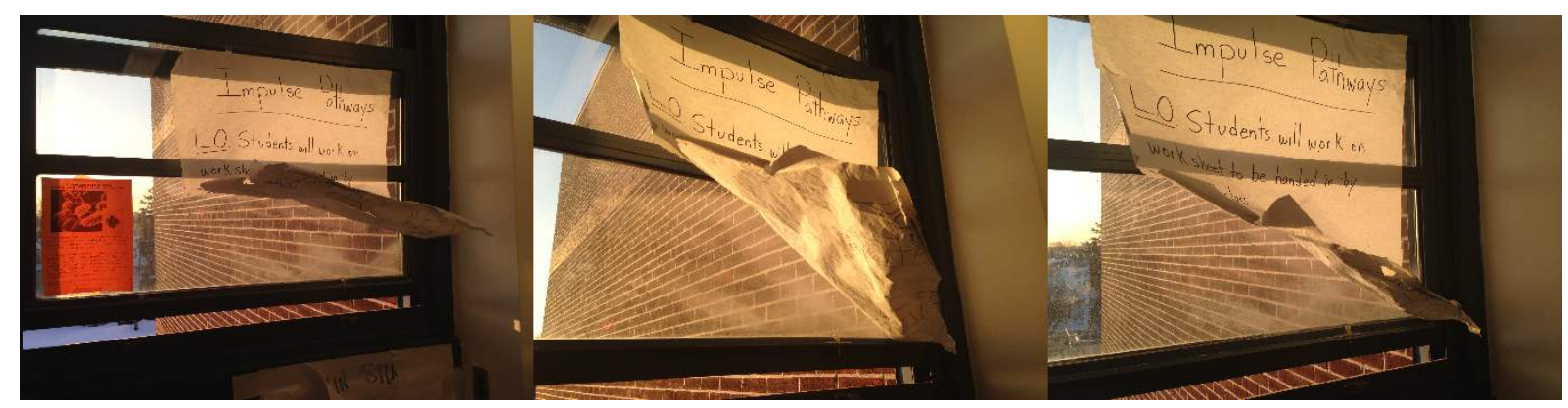

Figure 8- "Impulse Pathways"-Poster in front of classroom window. 


\section{Textures}

Certainly the textures of the classroom make up the everyday intimacies of learning. How many of us can remember moments of enrapture with a flap of paper wedged behind a staple on an acneravaged bulletin board? Have you ever encountered a kinship with a strip of chipping paint, that millimeter by millimeter you flaked away, a progress punctuated only by the teacher's grey eyes? Whose fingernails have not retraced the violent (desktop) bearings of a former student? Or who amongst us - not I-but I!- was bold (or bad) enough to make such a mark, to chip away at the smooth gloss of melamine, to uncloak for all future inhabitants the school's presumed untouchability? For Berlant (2000) "intimacy builds worlds; it creates spaces and usurps places meant for other kinds of relation" (p.2). The student who traces the lines of a past student joins in a public commentary on the traffic of bodies through school space and the affective drains of schooling. She handles this knowledge gently, lovingly and affirms its tacit presence in the classroom. Intimacies, for Berlant (2000), raise "questions of scale that link the instability of individual lives to the trajectories of the collective" (p.3). The tracing also quietly acknowledges the vibrancy (Bennett, 2010) of matter itself. The melamine of the desk carries the force of history; a desk is a composite of plastics, metal, formaldehyde, underbellies of gum and snot, a patina of finger oils.

A desk exudes what Bora (1997) terms texxture. Sedgwick (2003) elaborates: "Texxture is the kind of texture that is dense with offered information about how, substantively, historically, materially, it came into being" (Sedgwick, 2003, p.14). But perhaps there is a materiality to desk that moves beyond its traces of bodies and histories, and perhaps this "information" cannot be decoded. Bennett (2010) comments on an assemblage of items on the street - a dead rat, plastic and a piece of wood- and describes them emitting a form of liveliness. Though she acknowledges that her fascination with this tableaux might be "but a function of the subjective and intersubjective connotations, memories, and affects that had accumulated around [her] ideas of these items" she also submits the more startling proposition, "But what if the swarming activity inside my head was itself an instance of the vital materiality that also constituted the trash?" (p.10). We ask a similar question of classroom objects, such as a desk. There is a certain active motility to a desk as it weathers the passage of student bodies. The desk and student become an event (Phillips, 2006) taking on each other's forms and imprints (Figure 9).

By engaging classroom objects as sites we desired to come close to, to touch, we elicited encounters in which we hoped to allow our subjecthood to momentarily dissolve. By coming close to an object, by engaging too-close readings of it, and by no longer reading but becoming part of it, we become absorbed as a student might be absorbed in the classroom, perhaps by boredom or, as the teacher hopes, by total enrapt engagement (Ellsworth, 2005). Marks (2002) calls for "a visual erotics that offers its object to the viewer but only on the condition that its unknowability remain intact, and that the viewer, in coming closer, give up his or her own mastery" (p. 20). Our close encounters with classroom objects acted as a "giving-over to the other" (Marks, 2002, p. 20) that, in the process, disoriented our initial positioning as "researcher"-- a precarious role we held, lost, and found in the folds of chalk dust, orange sunlight, pencils, and rat bones. 


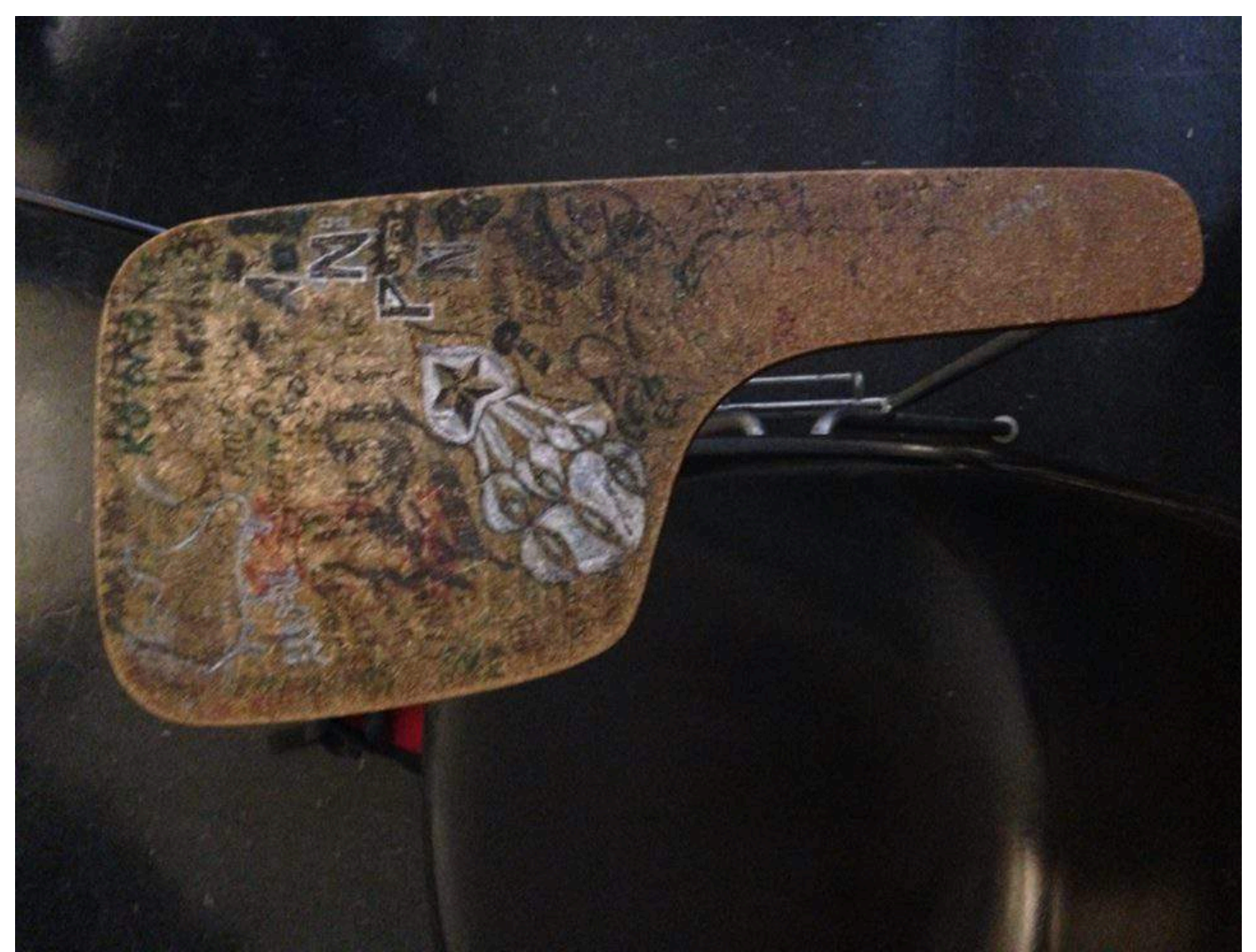

Figure 9- "Desk"-Classroom desk, NYC.

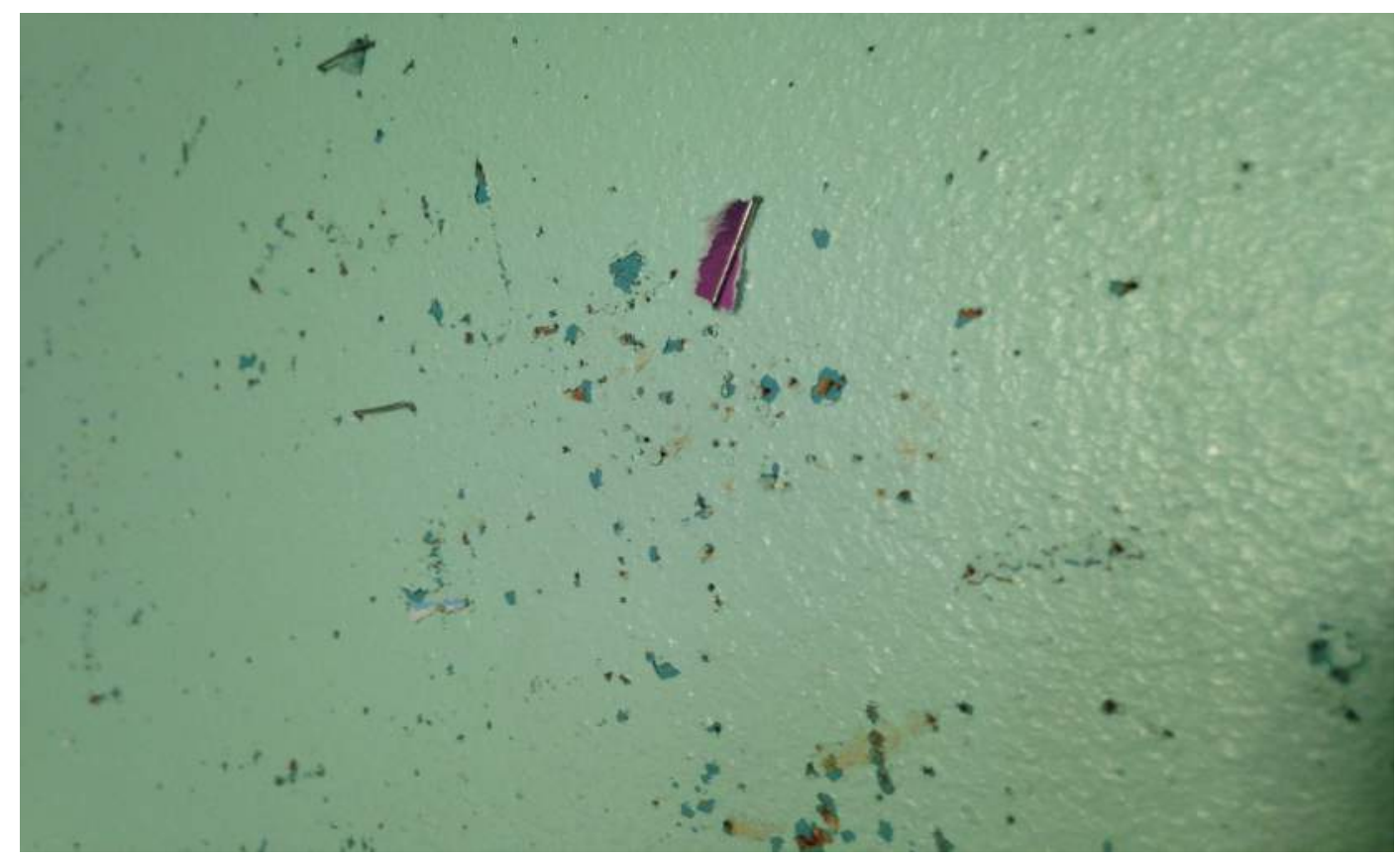

Figure 10- "Staple"-Detail of classroom bulletin board. 


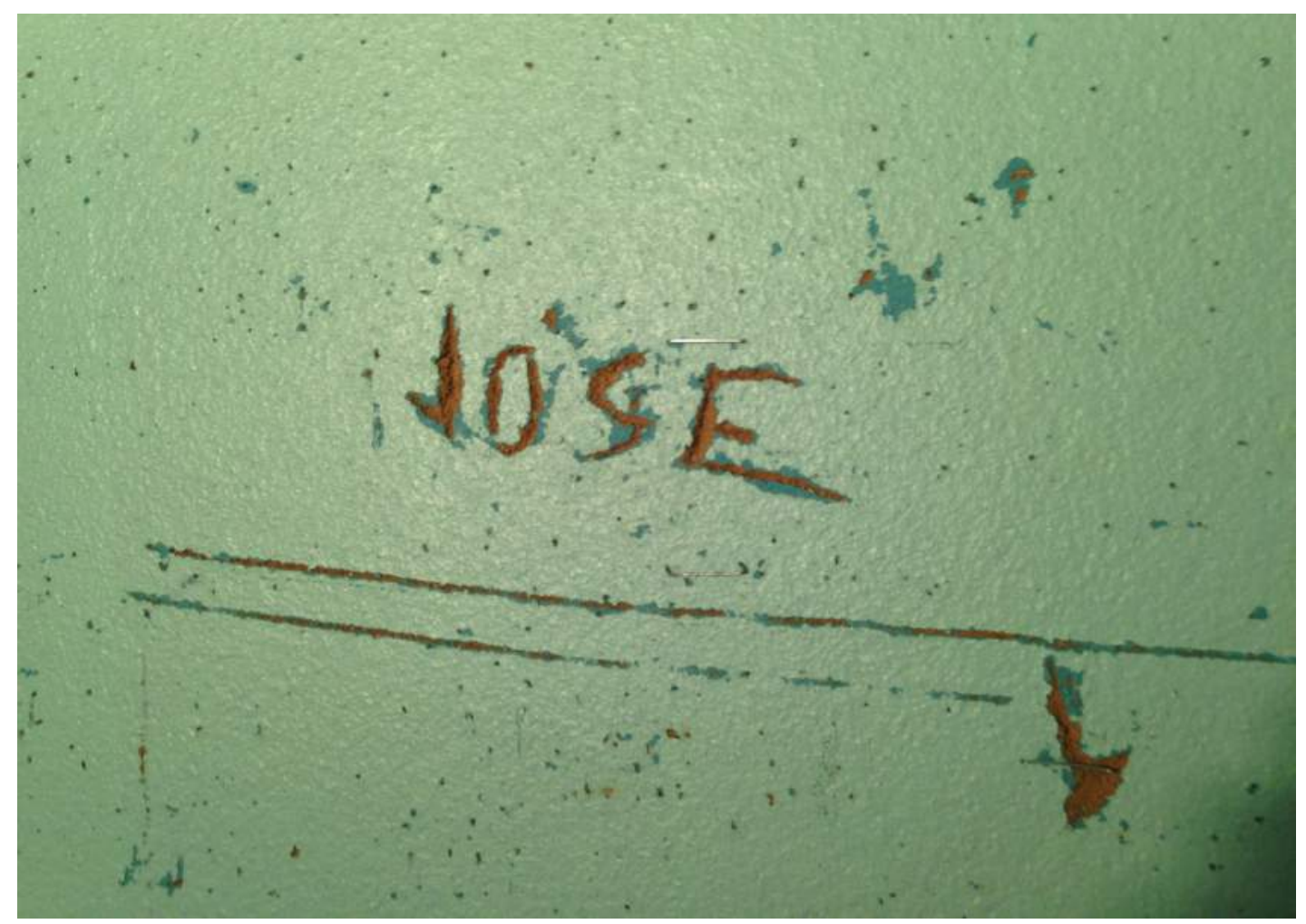

Figure 11- "Jose"-Detail of classroom bulletin board.

\section{Haptics}

To help attach to this vibrancy, the scenes and images that came out of this project attempt to move within what Marks (2002) deems 'haptic' theorizing. For Marks, the haptic marks a relationship of "[t]ouching, not mastering" (p. xii). As opposed to optic paradigms, which spur "our cultural tendency to take a distance' (p.xiii), a haptic relationship works to get close and "derive[s] theory from the objects themselves rather than impose theory on objects" (p.xiv). We see this as a particularly important intervention in schools since cool opticality is not only encouraged but valorized.

Objective, or cool, opticality can be seen in classroom observations, how a teacher circulates around a room to make sure all students are on task, increasing national pressures for visible "signs" of student learning. The optic paradigm maintains a distance between subject and object and positions the human in a Cartesian position of mastery over the world. It exercises a "sight divorced from every other sense" (Rothko, 2004) whereas the haptic paradigm entangles sight and touch, asking us to tend to an object's plasticity, to trace our "finger-eyes" (Hayward, 2008) along its surface.

Sedgwick (2003) describes touching as offering a form of theorizing outside of "dualistic thought and pedagogy" (p.1):

the sense of touch makes nonsense out of any dualistic understanding of agency and passivity; to touch is always already to reach out, to fondle, to heft, to tap, or to enfold, and always also to understand other people or natural forces as having effectually done so before oneself, if only in the making of the textured object. (p.14)

In working to embrace a haptic relationship to classroom objects, we wondered how we might make them, and how they might make us, feel differently and different. The materiality of the classroom welcomes us into our desks or position in front of the chalkboard; it disciplines us, and traces histories of other bodies, of resistances and boredoms, of power and (dis)obedience, of engrossments and distractions. Classroom objects invite "a surface reading always, a tracing to the 
bodily production of the sign that signifies only its refusal to reveal itself" (Brinkema, 2014, p.17). They invite us to engage intimate and close readings of their forms without co-opting, colonizing, or productively routing their bodies to meet our educative purposes. The familiar forms of the classroom summon known modes of relations while brimming with unrealized potentials. As Brinkema (2014) riffs off Deleuze's (1983) Spinoza-riff, "We do not yet know all it is that form can do" (p. 261). We sought to push the boundaries of those forms, or objects that constitute a shared sense of 'school'.

\section{Things}

To experiment with rather than interpret (Deleuze and Guattari, 1983) the materialities of the classroom, we brought outside objects in and played with the objects we found. Some of the objects we brought belonged in the classroom (such as pencils, Post-its, and tacks), signaled patternings of kinship and familiarity with school space, while others (such as wine, breastmilk, gum, a kitchen knife) felt particularly out of place in school. Like Kamprani's (ongoing) designs, the illicit objects jolted us when combined with familiar classroom objects. These unexpected combinations stoked both gleeful and fearful affective intensities as we subverted and flouted classroom norms. Do tacks on a chair (Figure 12) prick the skin with anticipation or fear? Do they recall elementary pranks on a teacher or unassuming peer? Do the tacks invoke guilt or shame at such memories? Does human milk on a desk inspire disgust? Does it cross a line we imagine for research; does it trespass a certain imagined sanctity of the school or an ethical relation to other bodies? Is breast milk harmless? Does wine pooling like blood on a test or a knife on a desk invoke an untoned violence to schooling, or is it cliché and predictable? Or do these objects stir nothing at all, always a potent possibility? 


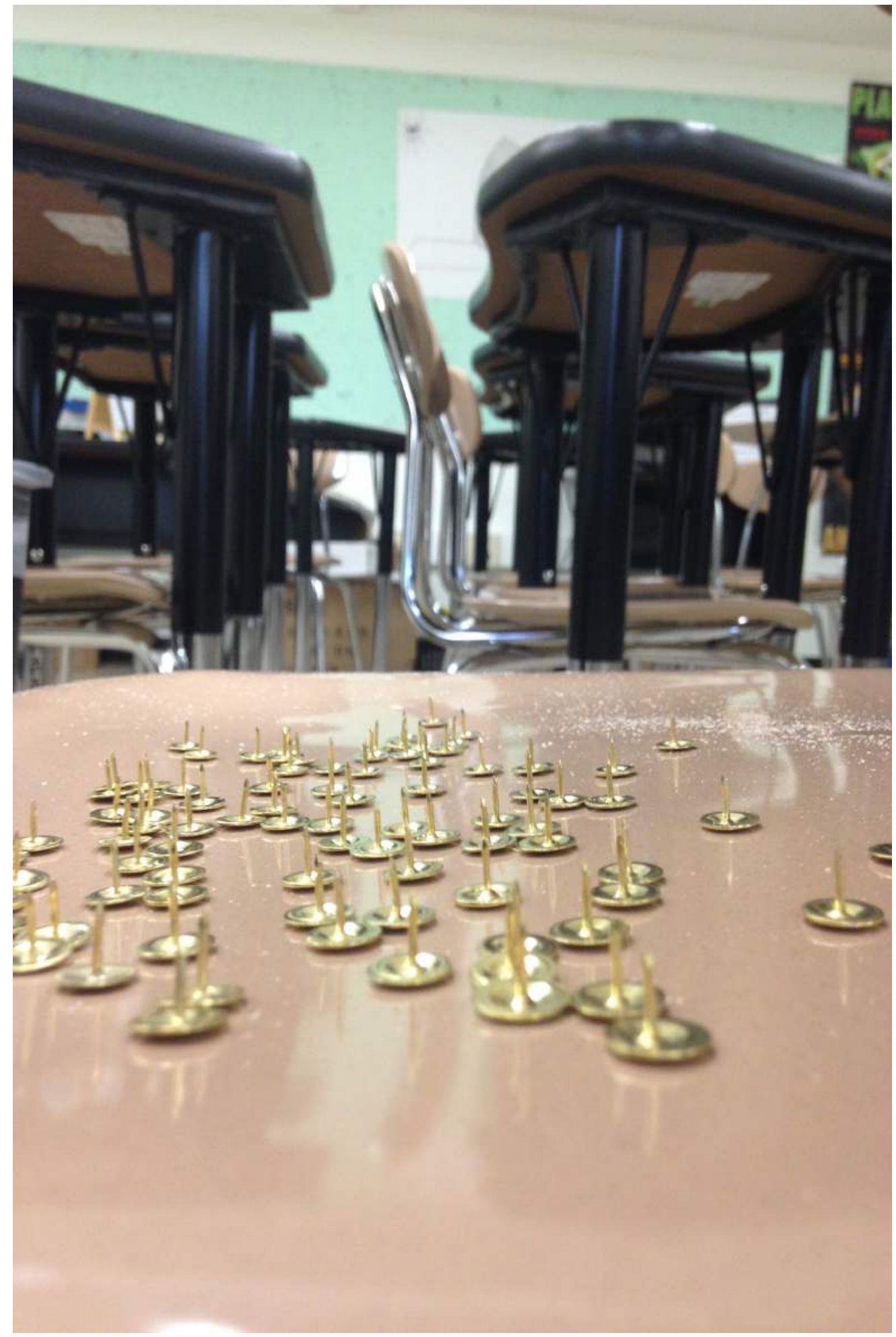

Figure 12- "Take a Seat"-Tacks on desk seat. 


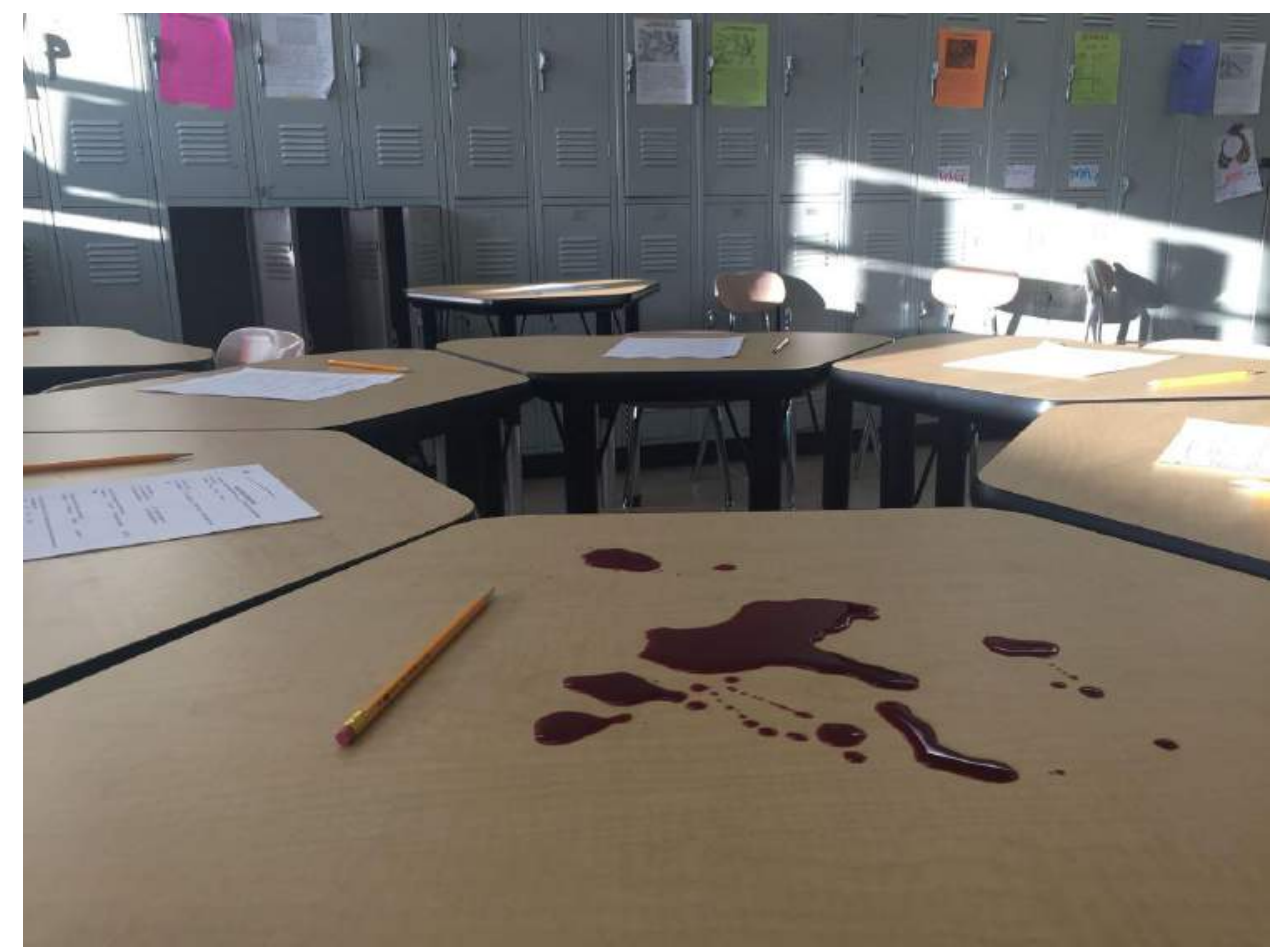

Figure 13- "Sharp"-Staging with desks, wine, sample exams, and pencils.

Sedgwick (2003) explores listing as an interruption to linear narration. A list moves vertically, but without hierarchizing. A list positions disparate items in intimate proximity, queerly connecting items that might not ordinarily "belong" together. The items on a list can be endlessly added to, crossed out, and revised. A list defers closure and completion. We offer below a listing to interrupt the standard narrative flow of a research report:

Things we brought:

tacks

a knife

rice cereal discarded because of arsenic warnings

breast milk

feathers

Maneshevitz wine left over from Purim (provided by the rabbi across the street)

pencils

Post-it notes

Saran wrap

tin foil

our bodies, hair \& shoes

gum and candy

chalk

Things we found:

sample state tests

books

an empty aquarium

pistachio shells

blackboard

Smart Board 
bulletin board

posters

an apple

flag

rat bones

dolls

desks

chairs

chart paper

teacher's notes

supply closet objects

lockers

At times we staged scenes, combining our household items with found school materials. We got very close to objects, playing with distance and scale. The outside objects changed the textures of the classroom. There were dangerous, sharp objects on the smooth surfaces of desks. Soft, pillowy textures on glossy melamine. Sticky warnings. Powders. Hair. Human fluids. Remnants of our and others' bodies. We staged objects into "scenes" of interruption, or intervention, and depended on quick, surface readings of those scenes. At first glance, the wine might be read as blood and the breast milk as milk, or semen, or cloudy waters from a leaky ceiling? What mattered to us wasn't the meaning of the thing, but how the thing in relation can ignite an uneasy feeling and mangle textures in ways that re-route our relationship to the classroom and unleash new affective intensities. By bringing objects into a classroom that do not "belong" and staging scenes with those objects, we played with entangling sight and touch in ways that disrupt the flow of (often flat) feelings sustained by the repetition of particular classroom objects and their anticipated arrangements.

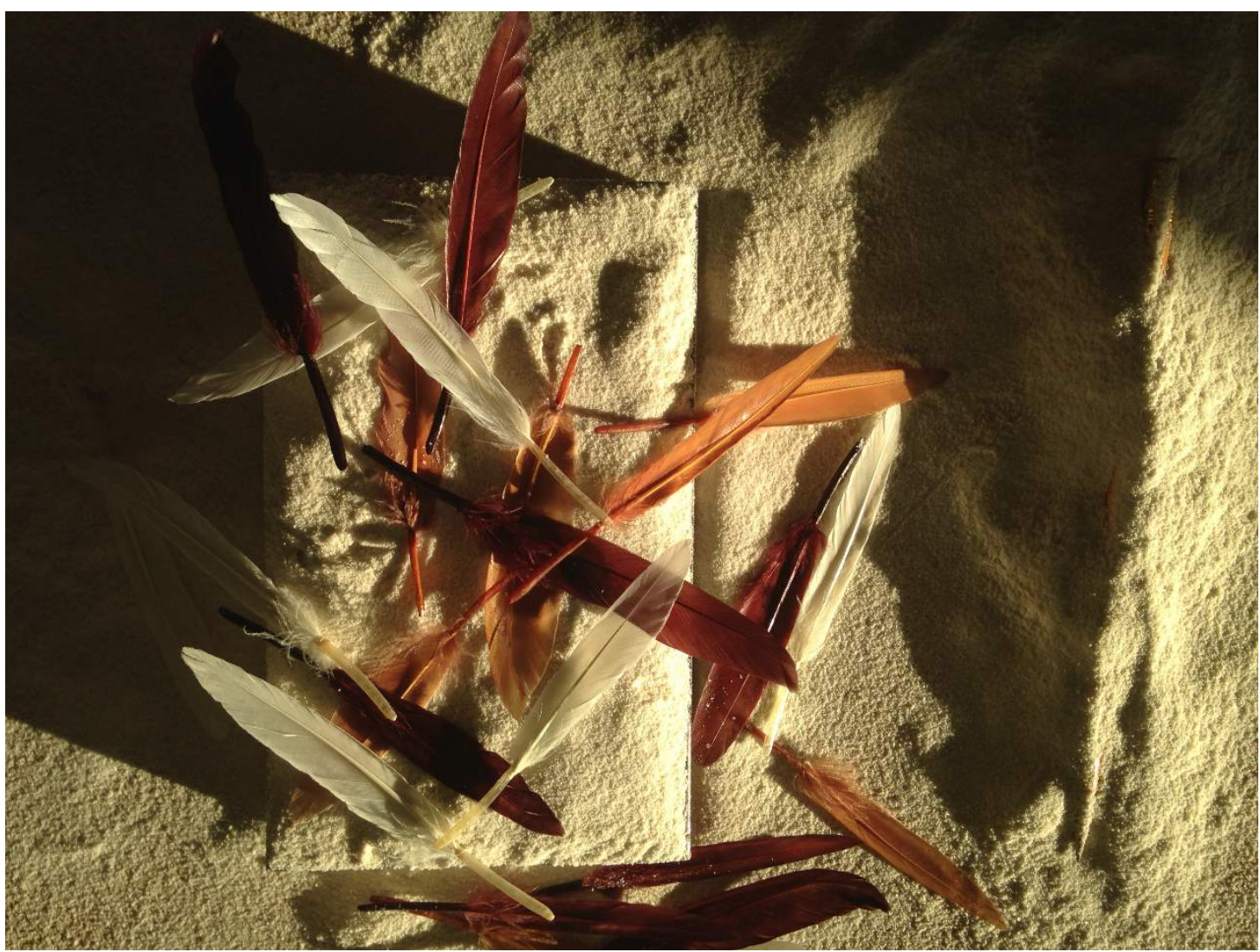

Figure 14- "Softcover"-Staging on desk with To kill a mockingbird, feathers, pencil, rice cereal 


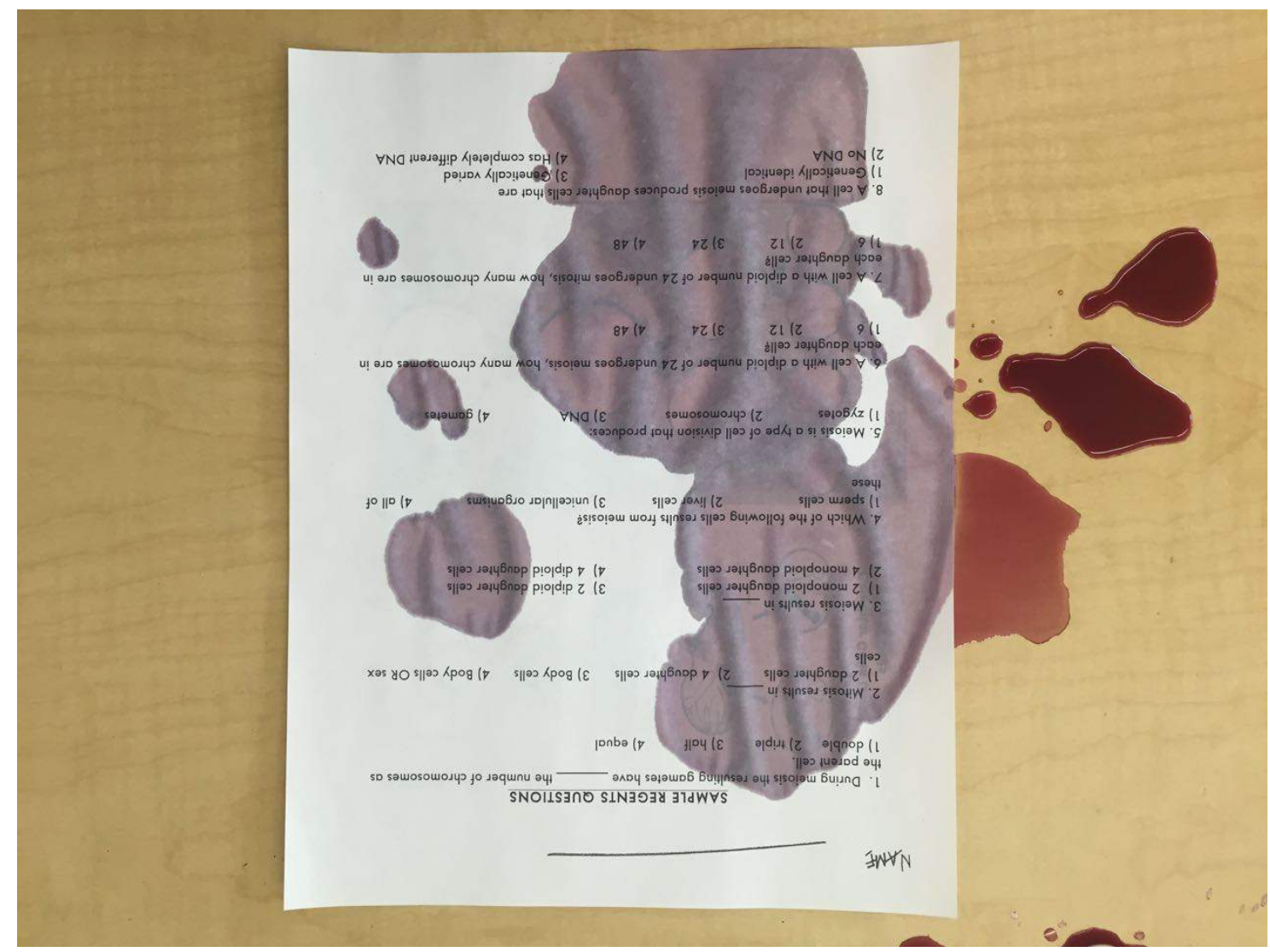

Figure 15: "Test Prep"-Staging with sample exam, desk, and wine

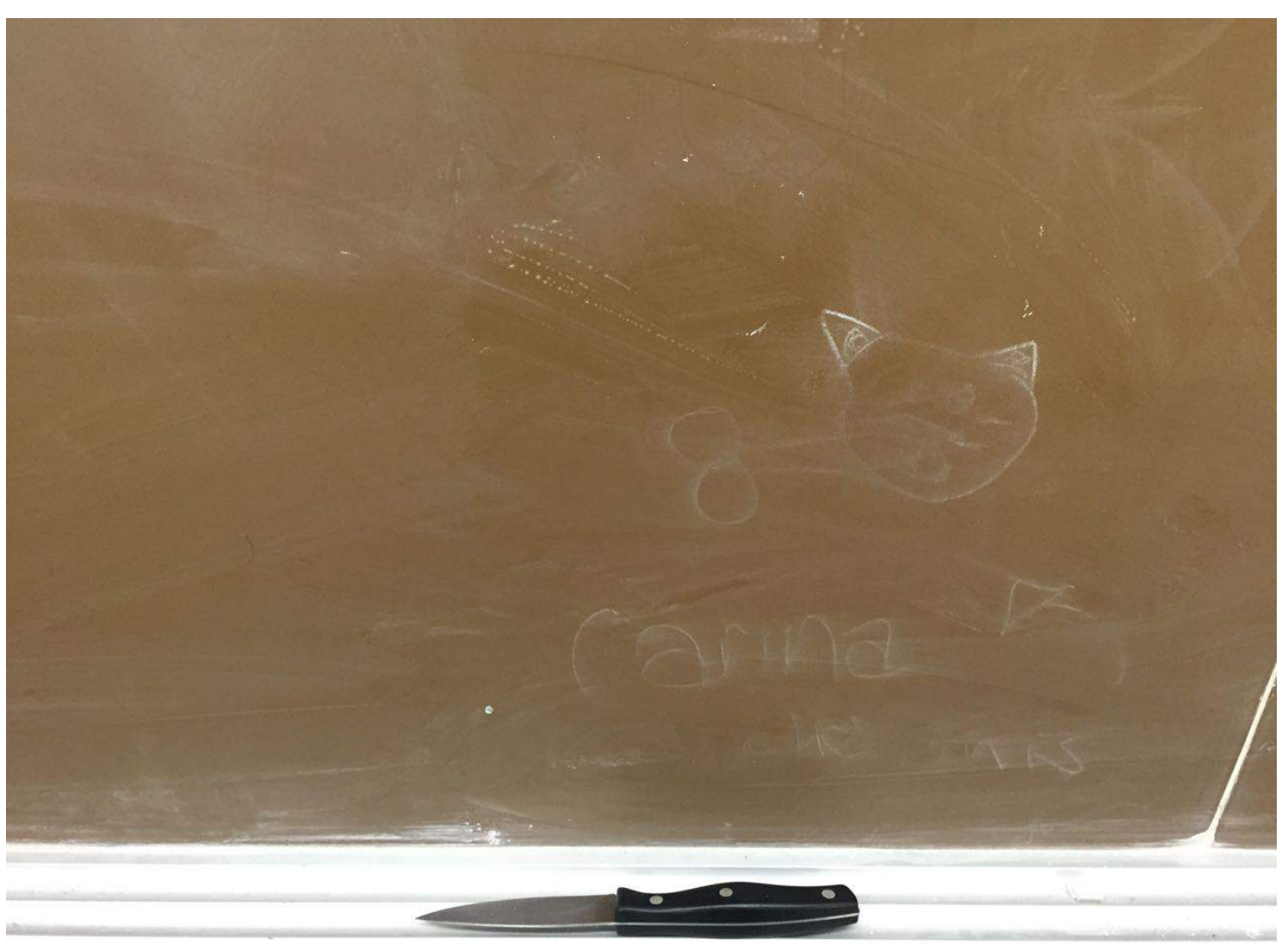

Figure 16-“Carina"-Kitchen knife on chalkboard shelf. 


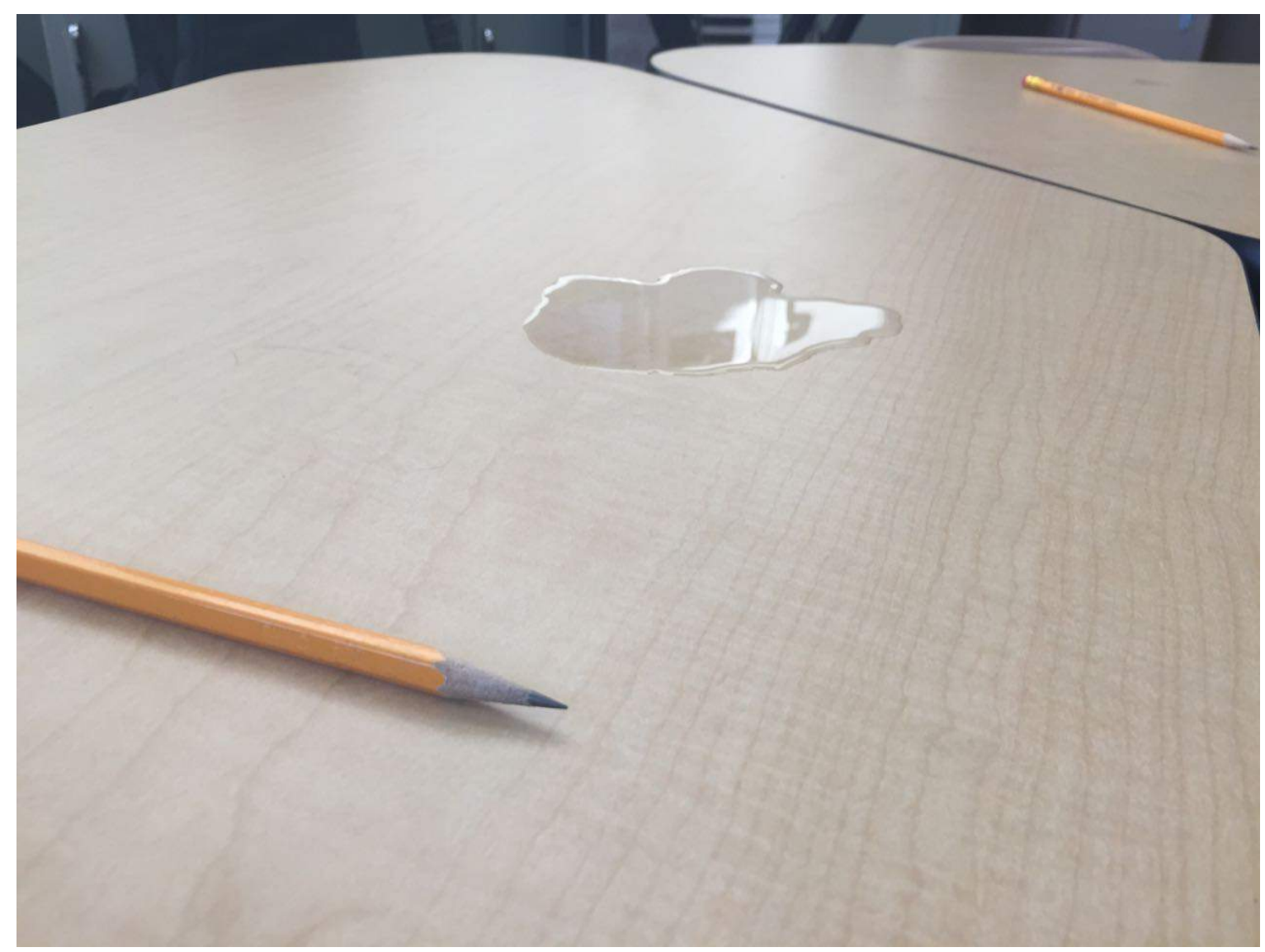

Figure 17- "Deskmilk"- Staging with pencil, desk, breast milk.

In Figure 17, a sharpened pencil lies next to a small puddle of breast milk, newly thawed after sitting in the freezer for two months. I (Maya) could not feed it to my daughter, but I could not bring myself to throw it out either. Spilled now over a classroom object so familiar to me as a teacher and student, the always--moving puddle makes possible the upside down reflection of lockers as it spreads slowly over the tree--ring-pattern of the desk's skin. The puddle acts like the mess it is --something to be cleaned up (which we later did with stringent cleaners). At the same time, in this photograph, the pairing of puddle and pencil evokes a possible metaphor, a poetic gesture, the remnant of an imagined event. The photograph captures the residue of a moment still fresh --the puddle appears wet and recent. The liquid could be anything: milk, water, semen. The pencil stays (maybe) a pencil, but newly infused with potentiality in relation to the mystery fluid inches away. The object that does not belong ("No drinking in class!") trespasses in this space, beckons the viewer to come closer, to feel the desk, to tentatively test with a touch or a wipe. Through strange juxtapositions, these familiar forms -- pencil, liquid, desk-- take on new affects made possible by their distinct relationality-in--context. They slip past the interpreter's grasp, asking instead for a kind of looking that scans the scene quickly, trusting the 'whatever' feeling comes from a fast glance (Marks, 2002). For Marks (2002), the haptic critic "tr[ies] to move along the surface of the object, rather than attempting to penetrate or 'interpret' it, as criticism is supposed to do" (p.xiii). Similarly, we tried to move quickly across the surface of these familiar subjects through intuitive, interruptive stagings. Through these quick stagings and shots, we followed our trust in these surfaces and played instinctively with these objects, favoring impulse over deep thought. The objects, it seemed, were open to toying, skimming, and tickles. 


\section{Felting}

As we touched and played with the classroom, our stagings elicited a tactile and haptic intimacy with the space. Following Stephanie Springgay's (2004; 2010) work on a/r/tography, the classroom materials, our bodies, questions, and research felted together into new assemblages of thinkingfeeling (Massumi, 2015). Springgay (2004) writes:

$\mathrm{a} / \mathrm{r} /$ tography is a process of aesthetic inquiry where questions are posed in such a way to open, rupture, and distress the research site and/or text. It is a process of un/folding, a felting that tangles knowledges through intentional fulling. In felting processes, individual strands of material [...] are rubbed together in such a way that they knot together creating new assemblages and new knowledges. It is an embodied tactile experience, moving both self (artist's hands and even full body) and object (hair) simultaneously, but not in similar directions. A/r/tography like felting requires that I search for meaning that is un/certain, eclipsed, and in tension. (p.44)

Felt is a provocative image of thought for haptic theorizing. Felt invites, almost demands, touch. Creating felt is also an embodied, sensory process. Fulling involves agitating and thickening wool (Martens, 2010). There is a fortuitous sounding of to have felt in felting-and, indeed, in this project past feelings attached to familiar classroom objects became entangled with new affects. Past and present, memory and touch, human and inhuman were put in tension. Felt, as Springgay (2004) explains, is itself a product of tension as barbed strands of hair hook onto each other. Unlike a weave, which retains the integrity of each strand and could ultimately be unravelled, felting produces a completely new formation that is irreparably entangled. As Deleuze and Guattari (1987) write, felt "[i]mplies no separation of threads, no intertwining, only an entanglement of fibers obtained by fulling (for example, by rolling the blocks of fibers back and forth). What becomes entangled are the microscales of the fibers" (p. 475).

Felt then bears a rich textural history of its process of production. One myth attributes the invention of felt as the result of making love on wool skins. The heat, friction, and moisture resulted in the happy accident of felt. ${ }^{2} \mathrm{~A}$ Christian myth attributes the invention of felt to Saint Clement who lined his shoes with wool and at the end of a long pilgrimage discovered he had worked the fibers into felt (Eiland III, 2007; Laufer, 1930). In both cases, "felted fibers are clearly understood to result from moisture and motion" (Eiland III, 2007, p.265). In felt, human and inhuman materialities mix and merge.

Felting, as a "nomad art" for Deleuze and Guattari (1987), demands "close-range vision, as distinguished from long-range vision; second, tactile, or rather haptic space, as distinguished from optical space" (p.492). Felting as research methodology invites embodied processes of exploring the micromaterialities of space as well as frictionally working and pressing against striated configurations (like school regulations, testing schedules, researcher subjectivities, and rigid configurations of classroom space in this instance). The stagings in this project were modes of felting the materials we brought with the classroom materials we found. The stagings and findings were a means of agitating the classroom's fibers and being agitated by them. Felting is also an apt image of thought for new materialist theorizing. It allows space for an intrinsic agency to materiality. Though humans may agitate wool, it is the entanglement of matter itself, a microscalar bonding of fibers (Eiland III, 2007), that produces felt. Indeed, when making felt by hand, many felters describe a moment of surprise when the wool transforms into felt. It is as if the wool suddenly comes to life. Felt, then, responds agentically to human touch and human touch responds to the animacy of materiality. For Barad

\footnotetext{
${ }^{2}$ Thank you to an anonymous reviewer for sharing this wonderful bit of knowledge.
} 
(2012), "[t]heorizing, a form of experimenting, is about being in touch" (p.207). Felting as a research methodology opens up what Barad (2012) sees as the various "questions of touching":

coupling and decoupling, entanglement, sensation, immersion, visual hapticity, ciliated sense, the synesthetic force of perceiving and feeling, contact, affective ecology, involution, strange and wonderful intimacies, sensory attunement, arousal, response, interspecies signaling, affectively charged multisensory dance, technological intimacies, remembering, figuring [...]. (p.207)

Our and the classroom's touches were just such questionings of intimacy and sensation, remembering and figuring, friction and tension. The urban classroom was a space we thought we knew after years of teaching, but its materialities taught us otherwise.

\section{Weak theory}

We cannot say that we set out to do and accomplished one thing. What we set out to do was disrupted by what the classroom itself offered (a classroom neither of us had seen before). It was disrupted by what we ended up doing inside this classroom (i.e. the stagings and photographs we took of our doings) and what was already there and underway. The planned and accidental, the staged and surprising, felted together into new modes of relating, thinking and doing the urban classroom.

Stewart (2008) takes up Sedgwick's (2003) notion of weak theory:

The perspective I find I have developed over these years and in these practices of attending and attuning to things is akin to what Eve Sedgwick calls "weak theory" (1997). Theory that comes unstuck from its own line of thought to follow the objects it encounters, or becomes undone by its attention to things that don't just add up but take on a life of their own as problems for thought. She calls this "reparative" theory-a good thing-in contrast to a "paranoid" or "strong" theory that defends itself against the puncturing of its dream of a perfect parallelism between the analytic subject, her concept, and the world-a kind of razed earth for academic conversation. (Stewart, 2008, p.72)

This paper has been such a reparative process of skimming surfaces and picking up and accumulating textures rather than seeking to tie up loose threads and offer fixed results or stable 'findings'. Places of learning are always coming into being and are never finished (Ellsworth, 2005). Rather than try to judge or accurately represent our doings, we "wonder where they might go and what potential modes of knowing, relating, and attending to things are already somehow present in them as a potential or resonance" (Stewart, 2008, p. 73). In traditional Mongolian feltmaking, an older layer of felt termed a "mother felt" is sometimes used as a base for new felt. After rolling and working the new layer of wool with the base, the fresh sheet of felt is separated from the mother felt (Kemery, 2006). Research and research methodologies are just such processes of frictional layering. Our work here felted off of countless other projects, ideas, and methodologies. Though we certainly do not want to position our work as foundational or originary by any means, we are interested in what ideas, projects, and experiments might similarly shear off this project into new formations. Each of us continues to follow classroom objects around in various classrooms, spaces, streets, for example, just yesterday: an old-school chair broken and belly-up with boot prints stuttering across it on the corner of 8th avenue and 5th Street in Brooklyn evokes curiosity to see where they might lead, what they might do, and what we might learn and feel. 
The question of what can never be fully known, or grasped and touched, through education invites a pondering of what one does, or can do, and how, maybe, most of all in schools, "Sagacity, must go" (Dickinson, 1998). As Dickinson (1998) writes in that same poem, "To guess it, puzzles scholars" and it is from this place of guessing and bewilderment that our research twitches. The objects that we followed as a way to intervene within a classroom invited us to engage them with love, memory, desire, and trust. It is from that place that we started this research and from that place that we hope to end; not with knowing, sagacity, and certainty, but rather with a weak theoretical map for further hiccups, haecceities, and haptic encounters.

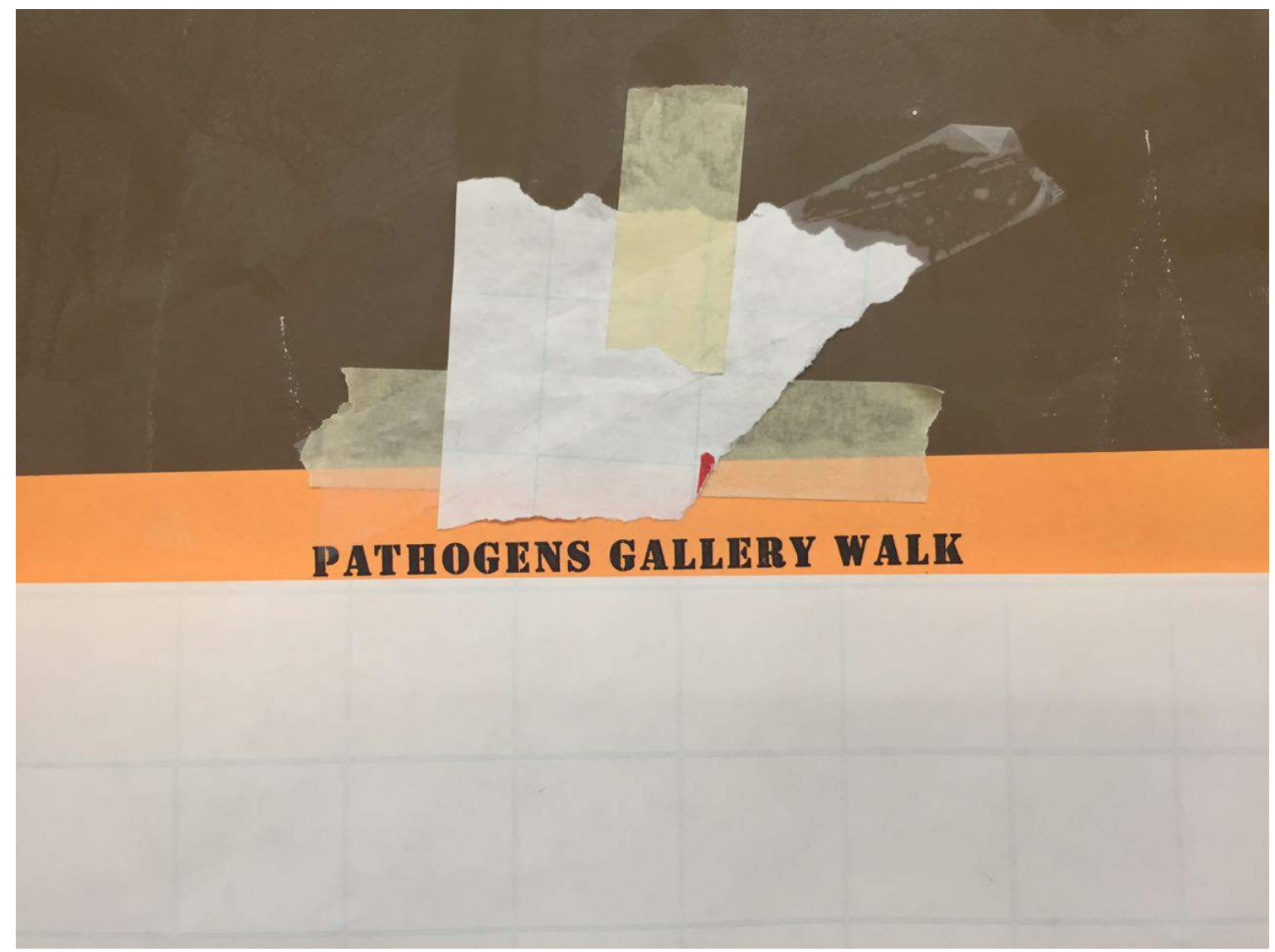

Figure 18- "Pathogens Gallery Walk"- Poster with tape.

\section{References}

Barad, K. (2007). Meeting the universe halfway: Quantum physics and the entanglement of matter and meaning. Durham, NC: Duke University Press. http://dx.doi.org/10.1215/9780822388128

Barad, K. (2012). On touching--The inhuman therefore I am. differences, 23(3), 206-223. http://dx.doi.org/10.1215/10407391-1892943

Berlant, L. (2000). Intimacy: A special issue. In L. Berlant (Ed.). Intimacy (pp. 1-8). Chicago,

IL: The University of Chicago Press.

Bodén, L. (2015). Dexter time: The space, time and matterings of school absence registration. Discourse: Studies in the Cultural Politics of Education. (E-publication ahead of print)

Bora, R. (1997). Outing texture. In E.K. Sedgwick (Ed.) Novel gazing: Queer readings in fiction (pp.94-127). Durham, NC: Duke University Press.

Brinkema, E. (2014). The form of the affects. Durham, NC: Duke University Press. http://dx.doi.org/10.1215/9780822376774

Chen, M. (2012). Animacies: Biopolitics, racial matters, and queer affect. Durham, NC: Duke 
University Press.

http://dx.doi.org/10.1215/9780822395447

Daza, S. \& Gerson, W. (2015). Beyond ocular inquiry: Sound, silence, and sonification. Qualitative Inquiry, 21, 639-644. http://dx.doi.org/10.1177/1077800414566692

Deleuze, G. \& Guattari, F. (1983). What is a minor literature? Trans. Robert Brinkley. Mississippi Review, 11(3), 13-33.

Deleuze, G. \& Guattari, F. (1987). A thousand plateaus: Capitalism and schizophrenia. Minneapolis, MN: University of Minnesota Press..

Dernikos, B. (2015). A gender gap in literacy? De/territorializing literacy, gender, and the humanist subject. Unpublished doctoral dissertation. Teachers College, Columbia University.

Dickinson, E. ([1800s] 1998). The poems of Emily Dickinson: Reading edition. R. W. Franklin [Ed.]. Boston: Harvard University Press.

Dolphijn, R. \& van der Tuin, I. (2012). New materialism. Ann Arbor, MI: Open Humanities Press.

Eiland III, M.L. (2007). Felting between east and west. Visual Anthropology, 20(4), 263-283. http://dx.doi.org/10.1080/08949460701424163

Ellsworth, E. (2005). Places of learning: Media, architecture, pedagogy. New York, NY: Routledge.

Fine, M. \& Ruglis, J. (2009). Circuits of dispossession: The racialized realignment of the public sphere for U.S. youth. Transforming Anthropology, 17(1), 20-33. http://dx.doi.org/10.1111/j.1548-7466.2009.01037.x

Fox, N. \& Alldred, P. (2015). New materialist social inquiry: Designs, methods, and the research-assemblage. Social Research Methodology, 18 (4), 399-414. http://dx.doi.org/10.1080/13645579.2014.921458

Hayward, E. (2008). More lessons from a starfish: Prefixial flesh and transspeciated selves. WSQ: Women's Studies Quarterly. 36(3\&4), 64-85. http://dx.doi.org/10.1353/wsq.0.0099

Helfenbein, R.J. (2015). Entanglement. Paper presented at American Education Research Association annual meeting. Chicago, IL.

Helmsing, M. (2015). Life at large: New materialisms for a (re)new(ing) curriculum of social studies education. Paper presented at American Education Research Association annual meeting. Chicago, IL.

Huddleston, G.S. (2015). The ideological weight of popular culture artifacts: The Walking Dead, Batman, professional wrestling, and neoliberal education reforms. Paper presented at American Education Research Association annual meeting. Chicago, IL.

Juelskjær, M. Staunæs, D. \& Ratner, H. (2013). Return of the Freudian Couch. International Journal of Qualitative Studies in Education, 26(9), 1132-1152. http://dx.doi.org/10.1080/09518398.2013.816885

Kamprani, K. (ongoing). The uncomfortable project. http://www.kkstudio.gr/projects/ the-uncomfortable. Accessed 15 August 2015.

Kemery, B. (2006). Yurts: Living in the round. Salt Lake City, UT: Gibbs Smith.

Kozol, J. (2012). Savage inequalities: Children in America's schools. New York, NY: Broadway Books.

Laufer, B. (1930). The early history of felt. American Anthropologist, 32(1), 1-18. http://dx.doi.org/10.1525/aa.1930.32.1.02a00020

Leander, K.M., Phillips, N.C. \& Taylor, K.H. (2010). The changing social spaces of learning: Mapping new mobilities. Review of Research in Education. 34, 329-394. http://dx.doi.org/10.3102/0091732X09358129

MacLure, M. (2013). Classification or wonder? Coding as an analytic practice in qualitative research. In R. Coleman \& J. Ringrose (Eds.), Deleuze and research methodologies (pp. 164184). Edinburgh: Edinburgh University Press.

Marks, L. U. (2002). Touch: Sensuous theory and multisensory media. Minneapolis: University of Minnesota Press. 
Martens, C. (2010). Feltmaking in Kyrgyzstan: A resilient tradition. Surface Design Journal, 12-19.

Massumi, B. (2015). Politics of affect. Malden, MA: Polity.

Mulcahy, D. (2012). Affective assemblages: Body matters in the pedagogic practices of contemporary school classrooms. Pedagogy, Culture \& Society. 20(1), 9-27. http://dx.doi.org/10.1080/14681366.2012.649413

O'Donaghue, D. (2006). Space and place in the making of masculinities in schools. Journal of Curriculum and Pedagogy, 3(1),15-33. http://dx.doi.org/10.1080/15505170.2006.10411569

Osgood, J. (2014). Playing with Gender: making space for post-human childhood(s) in J. Moyles, J. Payler, \& J. Georgeson (Eds.) Early Years Foundations: Critical Issues in Early Childhood (pp.191-202). Maidenhead: Open University Press.

Osgood, J. (2015). Reconfiguring play: material feminist possibilities to reimagine gender in early childhood. In J. Moyles (Ed). The excellence of play. Maidenhead: Open University Press.

Osgood, J. \& Scarlet, R.R./Giugni, M. (2015). Putting post humanist theory to work to reconfigure gender in early childhood: when theory becomes method becomes art. Global Studies of Childhood, 5(3), 346-360. http://dx.doi.org/10.1177/2043610615597160

Ranciere, J. (2004). The politics of aesthetics. New York: Bloomsbury Academic Publishing.

Renold, E. \& Ivinson, G. (2014). Horse-girl assemblages: Toward a post-human cartography of girls' desire in an ex-mining valleys community. Discourse: Studies in the Cultural Politics of Education. 35(3), 361-176. http://dx.doi.org/10.1080/01596306.2014.888841

Renold, E., Ivinson, G. Eliot \& Thomas. (in progress). Ruler skirt: Intra-activism, feminist materialist methodologies and the normalization of gendered violence in teen girls' peer cultures.

Renold, E. \& Mellor, D. (2013). Deleuze and Guattari in the nursery: Towards an ethnographic, multi-sensory mapping of gendered bodies and becomings. In R. Coleman and J. Ringrose. Deleuze and research methodologies (pp.23-41). Edinburgh: Edinburgh University Press.

Ringrose, J. \& Renold, E. (forthcoming 2016). Cows, cabin, and tweets: Posthuman intra-active affect and feminist fire in secondary school. In C. Taylor \& C. Hughes (Eds.) Posthuman research practiced in education. Palgrave MacMillan.

Rothko, M. (2004). The Artist's Reality: Philosophies of Art. New Haven, CT: Yale University Press.

Rotas, N. (2014). Sustaining the unsustainable: Wearable technologies as informing running-practice in urban schools. Reconceptualizing Educational Research Methodology. 5(2), 18-33. http://dx.doi.org/10.7577/rerm.1218

Sedgwick, E.K. (1997). (Ed.) Novel gazing: Queer readings in fiction. Durham, NC: Duke University Press.

Sedgwick, E.K. (2003). Touching feeling: Affect, pedagogy, performativity. Durham, NC: Duke University Press.

Snaza, N. (2015). Toward a "new" (old) materiality and temporality of education. Paper presented at American Education Research Association annual meeting. Chicago, IL.

Springgay, S. (2004). Inside the visible: Youth understanding of body knowledge through touch. Unpublished doctoral dissertation. The University of British Columbia.

Springgay, S. (2010). Knitting as an aesthetic of civic engagement: Re-conceptualizing feminist pedagogy through touch. Feminist Teacher, 20(20), 111-123. http://dx.doi.org/10.1353/ftr.2010.0009

Springgay, S. \& Rotas, N. (2014). How do you make a classroom like a work of art? Deleuzeguattarian methodologies of research-creation. International Journal of Qualitative Studies in Education, 28(5), 552-572. http://dx.doi.org/10.1080/09518398.2014.933913

Stewart, K. (2007). Ordinary affects. Durham, NC: Duke University Press. http://dx.doi.org/10.1215/9780822390404

Stewart, K. (2008) Weak theory in an unfinished world. Journal of Folklore Research, 45(1), 
71-82. http://dx.doi.org/10.2979/JFR.2008.45.1.71

Taylor, C. A., \& Ivinson, G. (2013). Material feminisms: New directions for education. Gender and Education, 25, 665-670. http://dx.doi.org/10.1080/09540253.2013.834617

Taylor, C. A. (2013) Objects, bodies and space: gender and embodied practices of mattering in the classroom. Gender and Education, 25(6), 688-703.

http://dx.doi.org/10.1080/09540253.2013.834864

Thiel, J. (2015). Shrinking in, spilling out, and living through: Affective energy as multimodal literacies In G..Enriquez, G., E. Johnson, S. Kontovourki and C. Mallozzi (Ed.). Literacies, learning and the body: Putting theory and research into pedagogical practice (pp.90-104). London: Routledge.

Tomkins, S. (1995). What are affects? In E.K. Sedgwick and A. Frank (Eds.). Shame and its sisters: A Silvan Tomkins reader. Durham, NC: Duke University Press.

Truman, S. (2015). Intratextual entanglements: Exploring text-based pedagogy among artists and philosophers. Paper presented at American Education Research Association annual meeting. Chicago, IL.

Zaliwiska, Z. (2015). Looking back-through: A posthumanist proposition. Paper presented at American Education Research Association annual meeting. Chicago, IL. 